18 Indonesian subjects aged 15 to 30 years with pancreatic calcification and diabetes. All were living on diets very low in protein and did not drink alcohol at all, and he thought the condition could well be due to protein malnutrition. There are striking changes in the pancreas in protein-calorie malnutrition in infants, and protein deficiency has been shown clinically and experimentally to diminish exocrine secretions and to produce histological changes in the pancreas. Ethionine, an antimetabolite of the essential amino-acid methionine, has been used experimentally to interfere with protein metabolism and to produce pancreatic lesions varying from mild atrophy to severe haemorrhagic necrosis. While there seems to be a great deal of experimental evidence to indicate that protein malnutrition can affect the pancreas adversely, it must be remembered that, in those children with kwashiorkor who recover, the recovery appears to be complete, and there has been no confirmed report of diabetes mellitus or pancreatic disease following kwashiorkor.

In conclusion, the pattern of pancreatitis seen in Kampala bears a significant resemblance to alcoholic pancreatitis. While many of its manifestations are less acute, overall it seems to be an even more severe process. Diabetes and malabsorption are very common, and the effects of malabsorption are far more pronounced than in the subjects referred to from Philadelphia (Howard, 1960). The whole process would appear to start at a somewhat earlier age and to run its course even more rapidly.

Little is known about the mechanism by which alcohol causes pancreatitis, and the current theory suggests that a high oral alcohol intake produces an increased volume of pancreatic juice via the secretin mechanism, against an obstruction produced by alcoholic duodenitis. It seems that alcohol played a part of some significance in about half of our cases, but it did so against a background of a low-protein high-carbohydrate diet. In those subjects seen in Kampala in whom alcohol was not a definite factor, was this due to an inadequate history, was this a protein malnutrition syndrome, or were there other factors which may have initiated lesions in a pancreas rendered vulnerable to injury by a low protein intake? There is as yet no firm evidence that protein malnutrition per se will produce irreversible pancreatic disease in adults.

It would seem that the condition of chronic pancreatic fibrosis with calcification seen in Uganda is not simply a problem of alcoholic pancreatitis, and it is almost certainly not a pure problem of protein malnutrition. Further studies are in progress to discover the incidence of this problem in the community and to assess the role of pancreatic injury in childhood in relation to chronic pancreatic diseases in later life.

\section{Summary}

The main clinical features present in 36 African subjects with pancreatic calcification are described and the possible aetiological factors discussed. The natural history of this disorder resembles that of alcoholic pancreatitis seen in other countries, and, while episodic heavy drinking (but not necessarily alcoholism) was noted in about half the subjects, it is emphasized that it took place against a background of low-protein high-carbohydrate nutrition. It is suggested that this tropical syndrome and alcoholic pancreatitis may have a similar pathogenesis, and that, in a pancreas rendered susceptible to injury by nutritional imbalance, alcohol and/or other factors may initiate progressive and irreversible pancreatic damage. It must be emphasized that this is not regarded as alcoholic pancreatitis, nor is it thought that the problem is purely one of protein malnutrition.

\section{REFERENCES}

Banwell, J. G., Campbell, J., Blackman, V., Hutt, M. S. R., and Leonard, P. (1963). E. Afr. med. F., 40, 277 .

Bourgoignie, J., Sonnet, J., and Dechef, G. (1962). Ann. Soc. belge Méd. trop., 42, 261.

Howard, J. M. (1960). In Surgical Diseases of the Pancreas, edited by J. M. Howard and G. L. Jordan. Pitman, London.

Kinnear, T. W. G. (1963). E. Afr. med. F., 40, 288.

Shaper, A. G. (1960). Lancet, 1, 1223.

(1961). Proceedings of 4 th Congress International Diabetes Federation, Geneva, 1, 119 .

and Patel, K. M. (1964). E. Afr. med. F. In press.

- and Shaper, L. (1958). Ibid., 35, 648.

Uganda Census (1959). East African Statistical Department, Entebbe.

Zuidema, P. J. (1959). Trop. geogr. Med., 11, 70.

\title{
Treatment of Typhoid Carriers with Ampicillin
}

\author{
A. B. CHRISTIE,* M.A., M.D., D.P.H., D.C.H.
}

Brit. med. F., 1964, 1, 1609-1611

The effect of chloramphenicol on the clinical course of typhoid fever has been one of the more dramatic triumphs of the antibiotic era: a long, low, muttering fever is converted into a short, sharp, febrile illness. Unfortunately its use in the acute stage does not guarantee that the convalescent patient is free from infection, and its effect in the established carrier has been very disappointing. Massive penicillin therapy, with or without the addition of sulphonamides or probenecid, has proved equally ineffective, and cholecystectomy has remained, in this age of antibiotics, the surest method of ending the carrier state. The present report deals with the treatment of eight typhoid carriers with ampicillin.

\section{Eight Carriers}

Seven of the eight carriers were mental-hospital patients, and had been in hospital for between 7 and 47 years: all were females. Six of them had been known typhoid carriers for between 7 and 27 years ; all six had had previous treatment for their carrier state, most of them several times, with penicillin and sulphonamides, streptomycin, furazolidone ("furoxone"), and chloramphenicol, with or without corticosteroids. The treatment was thorough but without effect. The seventh mental-hospital patient had been in hospital 36 years: she has been a known carrier only since 1962, though there is an unconfirmed record of her having been a carrier for 11 years before that ; there is no record of previous treatment. The eighth carrier worked in a school canteen: at the time of her discovery her hushand and son-in-law were suffering from typhoid fever, and one school child had caught the infection: she had no history of an illness like typhoid fever and the length of her carrier state is unknown.

Preliminary Surveillance.-The seven mental-hospital patients were put on bacterial surveillance for five months before treat-

\footnotetext{
* Physician-Superintendent, Fazakerley Hospital, Liverpool.
} 
ment was started: during that time they excreted Salmonella typhi in from 11 out of 43 to 43 out of 44 specimens of faeces. The eighth carrier was observed for two months, during part of which she was on chloramphenicol treatment, and she excreted Salm. typhi in the faeces in 31 out of 31 specimens. Details are shown in Table I.

\begin{tabular}{|c|c|c|c|c|c|}
\hline $\begin{array}{l}\text { Case } \\
\text { No. }\end{array}$ & $\begin{array}{l}\text { Years in } \\
\text { Mental } \\
\text { Hospital }\end{array}$ & $\begin{array}{l}\text { Years as } \\
\text { Carrier }\end{array}$ & $\begin{array}{l}\text { Previous } \\
\text { Treatment }\end{array}$ & $\begin{array}{c}\text { Faecal } \\
\text { Specimens } \\
\text { Positive } \\
\text { Before } \\
\text { Ampicillin }\end{array}$ & $\begin{array}{c}\text { Faecal } \\
\text { Specimens } \\
\text { Negative } \\
\text { After } \\
\text { Ampicillin }\end{array}$ \\
\hline $\begin{array}{l}1 \\
2 \\
3 \\
4\end{array}$ & $\begin{array}{r}7 \\
17 \\
20 \\
31 \\
\\
\\
36 \\
47 \\
\end{array}$ & $\begin{array}{c}7 \\
13 \\
12 \\
12 \\
\text { (Typhoid 53 } \\
\text { years ago) } \\
27 \\
26 \\
\text { Unknown }\end{array}$ & $\begin{array}{l}\text { C., P.-S. } \\
\text { C. } \\
\text { C., P. } \\
\text { C., Str., N. } \\
\text { C. } \\
\text { C. } \\
\text { None }\end{array}$ & $\begin{array}{l}17 / 31 \\
41 / 44 \\
11 / 43 \\
28 / 42 \\
\\
40 / 41 \\
40 / 44 \\
31 / 31\end{array}$ & $\begin{array}{c}100 / 100 \\
100 / 100 \\
100 / 100 \\
100 / 100 \\
\\
100 / 100 \\
100 / 100 \\
34 / 34\end{array}$ \\
\hline 8 & 36 & Unknown & $\begin{array}{l}\text { None } \\
\text { known }\end{array}$ & $\begin{array}{ll}\text { 1. } & 43 / 44 \\
\text { 2. } & 4 / 8 \\
\text { 3. } & 8 / 8\end{array}$ & $\begin{array}{c}\text { 44/44 } \\
\text { Relapse } \\
36 / 36 \\
\text { Relapse } \\
\text { Again negative }\end{array}$ \\
\hline
\end{tabular}

C. $=$ Chloramphenicol, one or more courses. P. = Penicillin. P.-S. = Combined penicillin and sulphonamides. Str. = Streptomycin. N.= Nitrofurantoin.

\section{Treatment with Ampicillin}

To treat carriers successfully ampicillin must be given in high doses for a long period. It was decided to treat the patients with oral ampicillin, supplemented by probenecid, for three months, and during the first week to give the drug by intramuscular injection as well. Ampicillin was not then available in injectable form and BRL 1060 was used instead. This is a mixture of the $\mathrm{D}$ and $\mathrm{L}$ isomers of $\alpha$-amino-benzylpenicillin and is only slightly less active than ampicillin, which is the $D$ isomer. The scheme of treatment is shown in Table II.

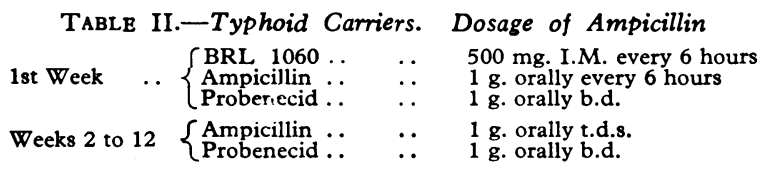

Toxic Effects.-Within the first fortnight two patients developed erythematous rashes, with scattered petechial elements. They were not otherwise upset, and their blood counts were normal. Treatment was not altered and the rashes disappeared. One of the two patients has had two further courses of oral ampicillin with no evidence of sensitivity. No other toxic reactions were observed.

\section{Results and Follow-up}

All eight carriers became abruptly negative within three days of starting treatment, and seven of the eight have remained negative for a year. Six of these seven are still in hospital, and, from each, 100 faecal specimens have been examined and all are negative. The seventh patient, the canteen worker, had to be allowed home, and surveillance with her could not be so thorough: nevertheless we kept her under observation for nine months, and 34 out of 34 specimens of faeces were negative.

With the eighth carrier the story is different. Before treatment 43 out of 44 specimens had been positive over a period of five months. Specimens became negative immediately treatment began; they remained negative throughout the threemonths course and for three months thereafter, a total of 44 out of 44 specimens being negative. She then began to re-excrete Salm. typhi, and during a month's observation four out of eight specimens were positive. She was then put on treatment again with oral ampicillin $1.5 \mathrm{~g}$. every six hours and probenecid 1 g. twice daily for one month. Specimens immediately became negative and remained negative for three months after treatment, 36 out of 36 specimens being negative. She then began again to excrete Salm. typhi, and in a period of four weeks eight out of eight specimens were positive. Straight $x$-ray film of the abdomen showed no gall-stones, but Salm. typhi was isolated from bile obtained by a duodenal tube. She has once more been put on treatment, and specimens have again become negative.

Gall-bladder Function.-In seven of the eight carriers gallbladder function has been investigated radiologically: one of the mental-hospital patients (Case 3 ) is bed-ridden and deformed, and examination was impossible. In Case 1 the gallbladder appears not to be functioning, though further investigation is required; but she has produced 100 negative specimens. In two more, though the gall-bladders appear to function normally, a small semi-opaque stone is present. In the remaining four, including the relapsing patient, the gall-bladders appear to function normally and no stones are present.

$V i$-agglutination Titres.-Specimens of blood were taken from six of the patients one year after the beginning of ampicillin treatment. The Vi-agglutination titres, correlated with the length of the carrier state and the response to treatment, are shown in Table III.

TABLE III.-Vi-agglutination Tests One Year After Ampicillin Therapy

\begin{tabular}{|c|c|c|c|}
\hline $\begin{array}{l}\text { Case } \\
\text { No. }\end{array}$ & $\begin{array}{l}\text { Years as } \\
\text { Carrier }\end{array}$ & $\begin{array}{l}\text { No. of Negative } \\
\text { Faecal Specimens }\end{array}$ & Vi titre \\
\hline $\begin{array}{l}1 \\
2 \\
3 \\
4 \\
6 \\
7\end{array}$ & $\begin{array}{l}7 \\
13 \\
12 \\
12(? 53) \\
26 \\
?\end{array}$ & $\begin{array}{c}100 / 100 \\
100 / 100 \\
100 / 100 \\
100 / 100 \\
100 / 100 \\
34 / 34\end{array}$ & $\begin{array}{c}1 / 20 \\
1 / 40 \\
1 / 20 \\
1 / 5 \\
1 / 80 \\
\text { Negative }\end{array}$ \\
\hline 8 & $?$ & $\left\{\begin{array}{l}\text { 44/44 Relapse } \\
36 / 36 \text { Relapse }\end{array}\right\}$ & $1 / 20$ \\
\hline
\end{tabular}

\section{Discussion}

While one hesitates to claim at this stage that any of the eight carriers has been cured, it is at least obvious that ampicillin has had a dramatic and profound effect on their carrier status, even in the patient who relapsed. The number of negative specimens necessary to establish cure must always be an arbitrary criterion. In the convalescent carrier six negative specimens at intervals of two to three days, with 12 in the case of nurses and 20 in the case of food-handlers, are usually regarded as reasonable. But in the case of chronic carriers tests of cure must be much more rigorous, and perhaps the length of total surveillance is more important than the final number of negative specimens. It is hoped, therefore, to continue tests on the seven patients still in hospital for another year.

The significance of the Vi-antibody test has never been fully established, and its value has recently been questioned (Public Health Laboratory Service Working Party, 1961 ; Bokkenhauser, 1964). If one accepts the conventional interpretation, that a titre over one in five indicates the presence of Salm.typhi in the body, then five out of seven of the patients I have tested must still be regarded as carriers, although four of the five have had 100 consecutive negative faecal specimens over the past year. But it may well be that where Vi antibodies have been established as a result of antigenic stimulation spread over periods of 7 to 26 years, they may be more difficult to dislodge from the serum than Salm. typhi, their antigen, from the faeces.

The length of treatment and the total dosage of ampicillin required for the treatment of the chronic carrier is still not settled. Troy (1964) treated three carriers with shorter courses and lower dosage than mine but cleared only one of the three 
by the first course; the second was cleared at the end of the second course of $750 \mathrm{mg}$. every six hours for one month, but the third only after a third course of $5 \mathrm{~g}$. a day for six weeks. Salm. typhi is an intracellular parasite, and it may be that treatment must be prolonged till cell death exposes the organism to the action of the drug. All that can be said from the present series is that a high daily dose of ampicillin, supplemented by probenecid and continued for three months, seems to produce very encouraging results.

Ampicillin appears to be not quite so effective as chloramphenicol in the treatment of the acute case of typhoid fever (Patel, 1964), though it would be interesting to know the final bacteriological results in a series of patients properly followed up. Relapses, both clinical and bacteriological, occur fairly often in patients treated with chloramphenicol, and it might be rewarding to give a course of ampicillin in the convalescent stage after the chloramphenicol, and to compare the bacteriological results with those obtained by chloramphenicol alone. And finally, although the chemoprophylaxis of any infection is a far from simple affair, and may result only in the prolongation of the incubation period rather than the eradication of the infection, a bactericidal drug is less likely to fail in prophylaxis than a bacteriostatic one (Petersdorf and Woodward, 1961). Ampicillin is bactericidal and its use in household contacts of typhoid fever might produce results comparable with those in contacts of smallpox treated by $\mathrm{N}$-methylisatin- $\beta$-thiosemi- carbazone (Bauer et al., 1963), though only a long-controlled trial could produce acceptable evidence.

\section{Summary}

Eight chronic typhoid carriers were treated with ampicillin for three months. All became abruptly negative as soon as treatment began, and seven have remained negative for a year. The eighth carrier has relapsed twice but has responded to further treatment with ampicillin on each occasion.

Supplies of ampicillin were generously provided by the manufacturers, Beecham Research Laboratories. I am indebted to Dr. O. P. W. Robinson, of Beecham Research Laboratories, for much comment and advice during the trials.

\section{REFERENCES}

Bauer, D. J., Vincent, L. St., Kempe, C. H., and Downie, A. W. (1963). Lancet, 2, 494.

Bokkenhauser, V. (1964). Amer. F. Publ. Hlth, 54, 477.

Patel, K. M. (1964). Brit. med. 7., 1, 907.

Petersdorf, R. G., and Woodward,' T. E. (1961). \%. Pediat., 58, 153 Public Health Laboratory Service Working Party (1961). \%. Hys. (Lond.), 59, 231 .

Troy, Patricia (1964). Brit. med. 7., 1, 1252.

\title{
Two Mediaeval Cases of Malignant Disease
}

\author{
CALVIN WELLS,* F.R.A.I., PH.D., M.R.C.S.
}

[With Special Plate]

Brit. med. F., 1964, 1, 1611-1612

A principal concern of palaeopathologists is not only to identify the occurrence of specific diseases in ancient populations but also to estimate the frequency with which these diseases occur. This is because the pathology of any community is always a reflection of its total environment and way of life ; hence the study of a group's morbidity will invariably give information about its living conditions. Often we find that an ancient population was afflicted by lesions which are identical with those found to-day: osteoarthritis, fractures, periostitis, paradontal abscesses, etc. Sometimes we can detect only a slight (albeit significant) difference between the ancient and modern incidence of these diseases.

Outstanding exceptions to this are malignant conditions, especially carcinomata. To-day these growths and their secondary deposits in bone are extremely common. In early burial grounds they are remarkably rare. Only three or four cases of indubitable carcinoma have been recognized among the tens of thousands of ancient Egyptian mummies and skeletons which have been examined. Hardly a score of such cancers have been identified from all the cemeteries of the preRenaissance world.

It is not my intention to review these cases here, though some very remarkable facts are disclosed by them. For example, despite the very small number involved several appear to have been nasopharyngeal in origin. One of the Romano-Egyptian cases described by Elliot Smith and Dawson (1924) was so

- Castle Museum, Norwich. situated, likewise another of about 3000 B.c. (Wells, 1963), another from precolumbian Chavina, Peru (Wells, 1964), a possible Neolithic one from Maiden Castle, Dorset (Goodman and Morant, 1940), and a strongly probable one from Tepe Hissar, Iran, c. 3000 B.c. (Krogman, 1940 ; Wells, 1964). In my Egyptian example the primary nasopharyngeal destruction of bone was obvious and was accompanied by many secondary deposits throughout the skull. No postcranial bones were present.

In view of the rarity with which cancer has been diagnosed in early peoples it is important to record all specimens which are discovered. Eventually a pattern of types and distribution may emerge. Two closely similar examples are described here.

\section{Case 1}

This consists of a single piece of a cranial vault (Special Plate, Fig. 1). It comprises approximately the posterior two-thirds of both parietals and the nearly complete squamous part of the occipital ; although no more of the body has been recovered the preservation of this fragment is excellent. It came from the churchyard of Stonar Church, near Sandwich, Kent, and the balance of evidence suggests that it is of fourteenth- or fifteenth-century date.

The obtrusive feature of this calva is the presence of a number of holes in it. These are undoubtedly pathological, not artifacts such as are sometimes found as the result of post-mortem damage by soil erosion, insect attack, or other causes. Three of these beles penetrate right through the bone, three involve only the diploë and 